\title{
The Standardization of Law and Its Effect on Developing Economies
}

\author{
Katharina Pistor
}

No. 4, June 2000 
UNITED NATIONS CONFERENCE ON

TRADE AND DEVELOPMENT
CENTER FOR INTERNATIONAL DEVELOPMENT

HARVARD UNIVERSITY

\section{G-24 Discussion Paper Series}

Research papers for the Intergovernmental Group of Twenty-Four on International Monetary Affairs

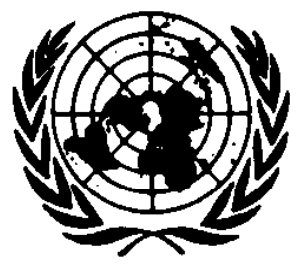

UNITED NATIONS

New York and Geneva, June 2000 


\section{Note}

Symbols of United Nations documents are composed of capital letters combined with figures. Mention of such a symbol indicates a reference to a United Nations document.

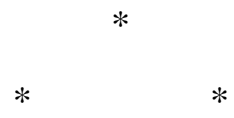

The views expressed in this Series are those of the authors and do not necessarily reflect the views of the UNCTAD secretariat. The designations employed and the presentation of the material do not imply the expression of any opinion whatsoever on the part of the Secretariat of the United Nations concerning the legal status of any country, territory, city or area, or of its authorities, or concerning the delimitation of its frontiers or boundaries.

Material in this publication may be freely quoted; acknowledgement, however, is requested (including reference to the document number). It would be appreciated if a copy of the publication containing the quotation were sent to the Editorial Assistant, Macroeconomic and Development Policies Branch, Division on Globalization and Development Strategies, UNCTAD, Palais des Nations, CH-1211 Geneva 10.

UNCTAD/GDS/MDPB/G24/4

UNITED NATIONS PUBLICATION

Copyright $\odot$ United Nations, 2000 All rights reserved 


\section{PREFACE}

The G-24 Discussion Paper Series is a collection of research papers prepared under the UNCTAD Project of Technical Support to the Intergovernmental Group of Twenty-Four on International Monetary Affairs (G-24). The G-24 was established in 1971 with a view to increasing the analytical capacity and the negotiating strength of the developing countries in discussions and negotiations in the international financial institutions. The G-24 is the only formal developing-country grouping within the IMF and the World Bank. Its meetings are open to all developing countries.

The G-24 Project, which is administered by UNCTAD's Macroeconomic and Development Policies Branch, aims at enhancing the understanding of policy makers in developing countries of the complex issues in the international monetary and financial system, and at raising the awareness outside developing countries of the need to introduce a development dimension into the discussion of international financial and institutional reform.

The research carried out under the project is coordinated by Professor Dani Rodrik, John F. Kennedy School of Government, Harvard University. The research papers are discussed among experts and policy makers at the meetings of the G-24 Technical Group, and provide inputs to the meetings of the G-24 Ministers and Deputies in their preparations for negotiations and discussions in the framework of the IMF's International Monetary and Financial Committee (formerly Interim Committee) and the Joint IMF/IBRD Development Committee, as well as in other forums. Previously, the research papers for the G-24 were published by UNCTAD in the collection International Monetary and Financial Issues for the 1990s. Between 1992 and 1999 more than 80 papers were published in 11 volumes of this collection, covering a wide range of monetary and financial issues of major interest to developing countries. Since the beginning of 2000 the studies are published jointly by UNCTAD and the Center for International Development at Harvard University in the G-24 Discussion Paper Series.

The Project of Technical Support to the G-24 receives generous financial support from the International Development Research Centre of Canada and the Governments of Denmark and the Netherlands, as well as contributions from the countries participating in the meetings of the G-24. 


\title{
THE STANDARDIZATION OF LAW AND ITS EFFECT ON DEVELOPING ECONOMIES
}

\author{
Katharina Pistor \\ Kennedy School of Government \\ Harvard University
}

G-24 Discussion Paper No. 4

June 2000 


\begin{abstract}
A widely used tool in law and development programmes is the supply of well-designed laws from the outside. This method of law development has now been embraced by international organizations as a way to improve the legal framework for global markets. The International Monetary Fund (IMF) has endorsed attempts by various organizations to develop legal standards with special emphasis on corporate and financial institution laws. The common idea behind these attempts is that the supplied laws once incorporated into domestic legal systems will improve the existing legal framework, and thus further economic development. This paper takes issue with this concept of law development. It argues that for developing effective legal systems, the contents of the supplied laws is of only secondary importance to the process of law development and the compatibility of the new laws with pre-existing conditions, including existing legislation and legal institutions. Three factors account for this: (i) only a few rules are freestanding, i.e. can be fully understood and enforced without reference to other legal terms and concepts; (ii) law is a cognitive institution, and the application and enforcement of rules is determined by the perception of new rules by users and enforcers in the receiving country; and (iii) effective law enforcement is a function of the extent of voluntary compliance and available resources in a given country. A closer analysis of the rules whose standardization is currently proposed for building an international financial architecture shows that the implementation of these standards and their effectuation will require more efforts by the law receiving countries than underwriting them, if the goals of standardizing the law are to be achieved. The paper discusses the implications for countries wishing to attract foreign investments by adopting the new standards, and makes some proposals for creating more effective legal systems in the area of financial law.
\end{abstract}




\section{Table of contents}

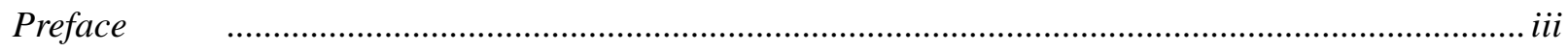

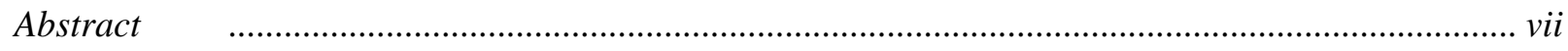

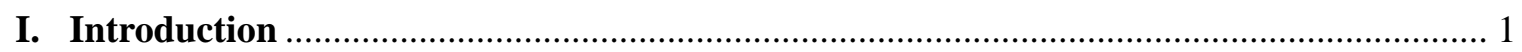

II. The perfect construction of law through international standardization ........................... 2

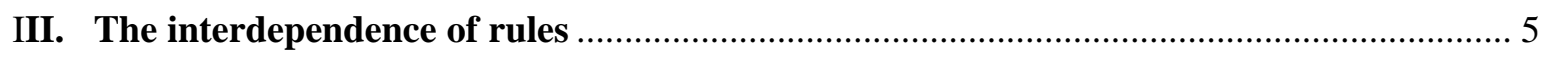

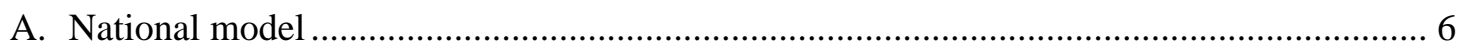

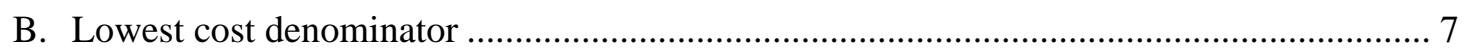

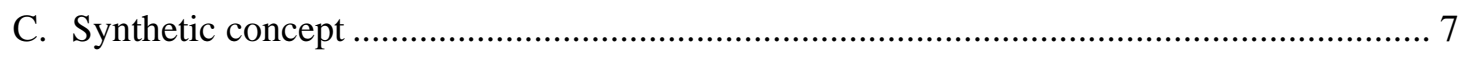

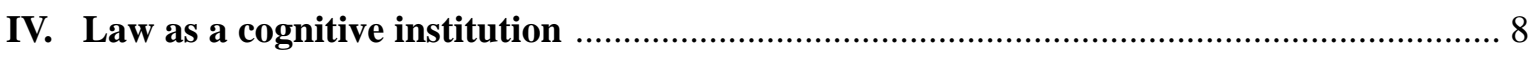

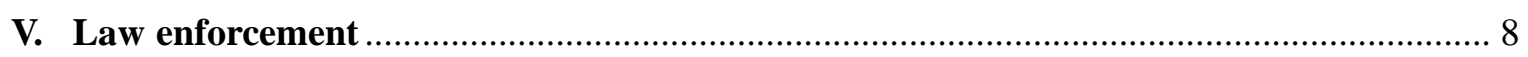

VI. Standardizing law for the international financial architecture ….................................. 9

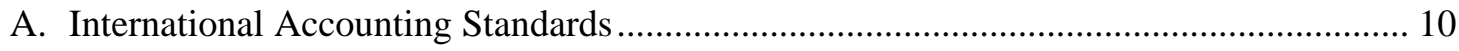

B. IOSCO Objectives and Principles of Securities Legislation ……..................................... 10

C. IAIS Insurance Principles, Standards and Guidance Papers ............................................. 12

D. OECD Principles on Corporate Governance ………........................................................ 13

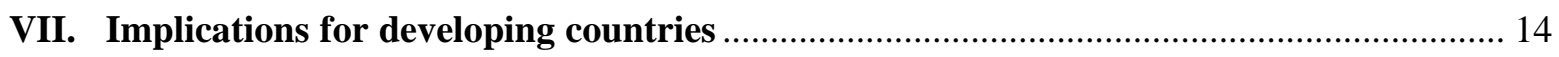

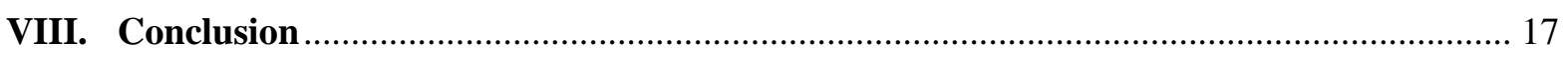

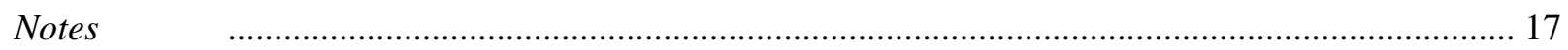

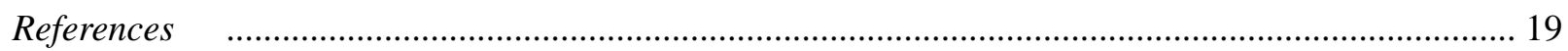




\title{
THE STANDARDIZATION OF LAW AND ITS EFFECT ON DEVELOPING ECONOMIES*
}

\author{
Katharina Pistor
}

\section{Introduction}

The integration of markets has gone hand in hand with a proliferation of efforts to harmonize key aspects of the law relating to finance and trade. Following the recent financial crises in Asia, Russia, and parts of Latin America, the International Monetary Fund has embarked on improving the international financial architecture, with special emphasis on the legal framework for corporate finance and corporate governance.

The vehicle for building the legal architecture for global markets is the harmonization of law around the globe by way of developing legal standards. ${ }^{1}$ These standards may be incorporated into international conventions, bilateral treaties, or retain the non-binding form of recommendations. The expectation is that standardization will accelerate the process of legal convergence, with the double benefit of reducing transaction costs for transnational investors and increasing the quality of legal institutions in countries whose institutions are less developed. This expectation is based on the assumption that convergence towards international legal standards will improve the institutional environment in the receiving country. The standards proposed have a clear normative agenda. At least at face value, ${ }^{2}$ their purpose is not simply to harmonize in order to re- duce transaction costs and to benefit from economies of scale, but to improve domestic legal institutions. ${ }^{3}$

The paper takes issue with this approach to reforming domestic legal systems. The proposed standards often do not hold what they promise, as will be further discussed in chapter VI. More importantly, the paper questions the assumption that legal harmonization will result in improvement of legal institutions. It argues that the quest for developing an optimal set of legal rules ignores a central feature of successful economic development, namely the constant change, innovation, and adaptation of institutions and organizations in a competitive environment. The standardization of "best practice" or "efficient" law replaces the Schumpeterian process of "creative destruction" with the ideal of the "perfect construction" of law. Instead of improving domestic legal systems, standardization or harmonization may in fact undermine the development of effective legal systems. The reason for this can be found in two essential features of legal systems. First, the interdependence of legal rules and concepts that comprise a legal system, and second, the fact that law is a cognitive institution. The interdependence of legal rules means that there are only very few rules that can be understood and applied without reference to other legal rules or concepts. This implies that standardized rules can be realized and enforced only if other bodies of law already exist in the standard receiving legal system, or

I should like to thank the participants of the G-24 Technical Group Meeting in Lima, 2-4 March 2000, as well as the participants at the MacArthur Transnational Economic Security Workshop at MIT, for their comments and suggestions. 
if additional law reform efforts are made. Without ensuring complementarity between the new law and pre-existing legal institutions, harmonization may distort rather than improve the domestic legal framework.

The notion that law is a cognitive institution means that for it to be effective and actually change behaviour, it must be fully understood and embraced not only by law enforcers, but also by those using the law, i.e. its "customers", or legal intermediaries, including courts, judges, etc. The external supply of best practice law, while facilitating more radical change than might be feasible without external pressure, sterilizes the process of law-making from political and socio-economic development, and thereby distances it from the process of continuous adaptation and innovation. The process of legal innovation depends on the availability of information not only about the contents of legal rules - something international legal standards do provide - but also about their functioning in the context of a living legal system. The perfect construction of law by legal experts for wide dissemination can deprive law makers and law enforcers in the receiving countries of the knowledge of living law, which is contextspecific. Moreover, the imposition of rules from the outside - not a new experience for most developing countries, as the history of colonization exemplifies - may also lead to domestic resistance. Thus, irrespective of the quality of the supplied legal standards, the paper questions the feasibility of using this approach for developing effective legal systems, i.e. legal systems that are capable of effectively enforcing laws and adapting them to a changing domestic and international environment. ${ }^{4}$

The development of effective domestic institutions is crucial for the governance of global markets, because without a supranational enforcement system, law enforcement is dependent on local institutions. Even in cases where disputes are settled by international arbitration tribunals in accordance with international arbitration standards, domestic courts will need to recognize the award. Domestic bailiffs, court enforcers, sheriffs, etc., will need to seize assets, freeze bank accounts, or take other actions to execute the award should the parties fail to comply voluntarily. Thus, the standardization of law does not solve the problem of transnational transactions being governed by multiple jurisdictions. At best, it may reduce uncertainty about the substance of the applicable law. Standardization, however, is not a guarantee for uniform interpretation and enforcement of set standards.
A more fundamental issue that is not addressed in this paper is whether the areas of the law currently targeted by IMF standardization claims are in fact the most relevant areas for legal reforms by developing countries. While there is some empirical evidence that equity markets are important determinants of economic growth (Levine and Zervos, 1996; Levine, 1998), ${ }^{5}$ comparative data also suggest that countries need to cross a certain threshold in their income levels before viable securities markets can take off. More importantly from the point of view of legal development, most of the proposed reforms depend on the existence of a fairly developed and well functioning legal infrastructure. Without this infrastructure, reforms in the proposed areas of accounting standards, securities legislation, insurance regulation, and even corporate governance will remain at the surface. In most of this paper, however, we shall not question the relevance of reforms in these areas of the law, but focus on the question whether the desirable improvements in domestic legal institutions can be achieved by adopting legal standards.

The paper is organized as follows: chapter II gives an overview of the most important standardization efforts for the international financial architecture that are currently underway, assesses the justification for harmonizing law in these areas, and reviews the debate about the costs and benefits of harmonization versus regulatory competition; chapter III discusses the problem of the interdependence of standardized rules within the pre-existing legal system; chapter IV introduces the concept of law as a cognitive institution; chapter $\mathrm{V}$ discusses the propensity of newly introduced standards to affect behaviour, i.e. the problem of law enforcement; chapter VI applies this framework to the legal rules that form the core of the international financial architecture; chapter VII discusses the possible implications for attracting foreign investments by countries that subscribe to standardized rules, and develops some policy proposals for improving the effectiveness of legal institutions as an alternative or complement to adopting standardized rules.

\section{The perfect construction of law through international standardization}

The current trend towards globalization of markets has not invented but re-enforced the idea of defining a common core of legal standards. The most prominent example for legal harmonization of financial market regulations is the Basle Capital Accord 
of 1988 , which established capital adequacy rules for banking engaging in cross-border activities. ${ }^{6}$ The integration of financial markets, in particular the massive flow of international capital to emerging markets, has exposed the legal and institutional environment of these countries to pressures they were often not able to withstand. ${ }^{7}$ In response to the recent financial crises in emerging markets, the governance of markets, firms and intermediaries has become the focal point of attention.

The legal standardization efforts identified by the International Monetary Fund to be of primary importance for the international financial architecture, in addition to banking regulation, include accounting, auditing, bankruptcy, corporate governance, insurance regulation and securities market regulation. ${ }^{8}$ Various entities are involved in developing legal standards for these areas of law. Some are professional interest groups whose members come primarily from the private sector. An example is the International Federation of Accountants (IFAC). Others recruit their members from national regulatory agencies. Both the International Association of Insurance Supervisors (IAIS) and the International Organization of Securities Commissions (IOSCO) represent this category of international standard setters. In addition, several multilateral organizations are involved in building the legal architecture for global markets. The United Nations Commission on International Trade Law (UNCITRAL) has a long record of developing model laws and international conventions, ${ }^{9}$ and has recently adopted a Model Law on Crossborder Insolvency. UNCITRAL collaborates with the World Bank and the International Bar Association (IBA) in developing a model law for domestic bankruptcy law. Finally, the Organization for Economic Cooperation and Development (OECD) has recently adopted standards for corporate governance, the so-called "Principles of Corporate Governance". In addition, the OECD has developed a separate set of corporate governance principles for transition economies. The World Bank is also engaged in improving the framework for corporate governance in many of its lending countries.

A common feature of the above listed standardization efforts is their non-binding nature. All take the form of recommendations directed at the members of their organizations. In cases where sovereign States are members, the addressees of the standards are law makers. Where members are primarily private parties - as is the case with the International Accounting Standards Committee (IASC) - the standards pursue, at least implicitly, a dual goal: a bottom-up dissemination of standards through their adoption by individual companies and firms, and a lobbying effort for legislative change to incorporate the organization's standards into domestic law. ${ }^{10}$

Another feature of the financial law standards is that they tend to be general in nature rather than specific, and leave ample scope for their interpretation to law makers and law enforcers. Rather than harmonizing highly specified rules, the standards aim only at establishing the principles for such rules. This means that there is no attempt to force a single set of rules - the perfect law - upon sovereign law makers around the world. In principle, countries can therefore choose not to adopt these standards, and are free to modify them where appropriate. Yet, the aim of standardization is to minimize deviations from the standards, lest the very purpose of standardization is undermined. Most standard setters are therefore quite explicit about the need to abide as closely as possible by the standards. ${ }^{11}$ Moreover, the endorsement that legal standardization has received from the IMF strongly suggests that these standards may serve to assess the quality of domestic laws in the future. It also leaves open the possibility for them to be used as conditionalities in loan agreements.

The voluntary and non-binding nature of legal standards reduces the degree to which law will actually be harmonized across jurisdictions, and by implication it reduces the possible savings for transnational investors as a result of the standardization effort. However, it gives countries greater scope for taking an active role in the reception of these standards and their transformation into domestic law. This requires that domestic law makers have a good sense of the purpose of the proposed rules and the alternative choices for detailed rule-making they may entail, which in turn presupposes familiarity with living legal systems. The supply of ready-made standards to domestic law makers does not facilitate, and may actually impede, the acquisition of this knowledge. Legal standards developed at the supranational level are typically distilled from legal practice in individual countries, without their merits having been tested in a functioning legal system. The generality of standards may also disguise the fact that they often entail a substantial reallocation of rights with important implications for the political economy of enforcing them within a domestic setting. At the same time, their generality opens up the possibility for subscribing to them without necessarily implementing them. ${ }^{12}$ This makes not only monitoring of compliance difficult, but also misguides investors, who may take the fact that a country has formally subscribed to a stand- 
ard as evidence that the law is in fact used and enforced in a certain way. Alternatively, investors may take the signals for what they are - formal or creative compliance with international standards. While they may perfectly understand that this does not necessarily increase the security of their investments in the long term, they will at least have covered their back vis-à-vis their own superiors and ultimately their investors. ${ }^{13}$ However, if subsequent experience reveals that these assumptions are wrong, this may increase rather than reduce uncertainty as to how to assess the investment environment of a given country. Conversely, countries that are actually complying in practice with these standards may experience signalling problems, as the law on the books will loose its signalling power.

Developing international legal standards and adapting legal systems around the world to these standards is a costly undertaking, and thus requires some justification. The harmonization or standardization of law can be questioned on principle grounds, irrespective of the area of the law in question and the quality of the standards that may emerge from the effort. This is the topic of the debate over the costs and benefits of harmonization versus regulatory competition in producing better rules from an economic efficiency point of view. ${ }^{14}$ This debate has long focused on law development within domestic legal systems, in particular federal systems, but has more recently also embraced the topic of law development in a global economy. Advocates of harmonization claim that minimum standards are needed to prevent a race to the bottom between different jurisdictions. Countries around the world compete for capital and, in order to attract foreign capital, they will tend to offer lax rules in the relevant areas of law, including tax, torts, environmental protection and financial market regulation. Moreover, harmonized legal rules will lower transaction costs, and therefore foster international trade and commerce. Proponents of regulatory competition argue that harmonization will result in sub-optimal rules: Different reasons are put forward to support this point of view. The process of selecting legal standards that are to be harmonized may lead to the choice of the lowest common denominator, instead of the most efficient rule. Where there is little certainty about the right choice, as in most cases, harmonization will lock a large number of jurisdictions into sub-optimal rules and prevent flexible adaptation to better rules and to changing circumstances. Instead, competition between regulators will lead to a race to the top and bring about efficient rules, because experience will teach regulators that in the long term they will ben- efit from adequate protection of investors and a high quality legal system.

Some authors have developed a more attenuated assessment of the relative costs and benefits of harmonization versus regulatory competition. ${ }^{15}$ They argue that both harmonization and regulatory competition tend to lead to indeterminacies and thus to suboptimal legal rules, albeit for different reasons. In the case of legal harmonization, the diversity of opinions and the necessity to compromise lead to indeterminacy. When experts are in charge of developing legal standards, they may have incentives to ensure the need for their services in the future. The use of open-ended terms typically requires further expert consultation, and indeed can be frequently found in private law-making activities. ${ }^{16}$ But regulatory competition may also lead to indeterminacies. ${ }^{17}$ Once a regulatory system has established a head start over others, it benefits from rules that can be interpreted and applied only within that regulatory regime. Superior legal expertise of attorneys and judges is an important asset that is not easily emulated by other jurisdictions. ${ }^{18}$ This advantage can be re-enforced by developing rules that require their expertise. An important implication of this debate is that the outcome of the law-making process is not independent of that process.

But the quality of the law that results from decentralized or centralized law-making may not be the only reason for or against harmonizing law, or developing international standards for certain areas of the law. From the menu of possible justifications for harmonization efforts (Leebron, 1996: 51-66), we choose the ones that are relevant for the assessment of those standards this paper focuses on, including jurisdictional interface; the presence of externalities; the non-efficiency of unilateral rules; political economies of scale; and transparency.

An important justification for harmonization is the interface of different jurisdictions in cases that involve more than one jurisdiction and the difficulty in reconciling different legal regimes. The UNCITRAL Model Law on Transnational Bankruptcy is a case of interface harmonization of legal rules. No attempt is made to standardize domestic rules for all bankruptcy cases. The goal is to reduce transaction costs and increase certainty only for those cases that are at the interface between different jurisdictions without necessitating far-reaching domestic change.

The International Accounting Standards (IAS) pursue a dual role. They seek to establish a common 
set of accounting standards independent of domestic legislation, and to convince domestic law makers to adopt these standards. The latter goal is intended to improve local institutions, but it is not a necessary condition for achieving the first goal. This goal can be justified primarily on grounds of economies of scale and transparency. If all companies in the international market disclose their financial information according to the same standards, transparency will be greatly increased and transaction costs reduced for investors as well as for firms monitoring each other's activities.

The other standardization efforts listed above target primarily domestic legal institutions, even though the standards of IOSCO and IAIS also aim at improving collaboration between national supervisors in coping with cross-border transactions. The standardization of domestic securities market regulation could be justified on the grounds that negative externalities of movements in the stock market in one country or region of the world should be avoided. The 1997/98 financial crisis in Asia had a strong contagion effect on other emerging markets. Studies have shown that the quality of domestic law has played an important role in buffering the effects of the crisis. Countries with better laws on the books and more effective legal institutions were more likely to weather the storms of the crisis than countries where shareholder protection was only weak on the books as well as in practice. ${ }^{19}$ Another justification would be that the fungibility of securities makes it difficult for each country to unilaterally enforce its laws. ${ }^{20}$ Thus, there is a strong theoretical possibility of a race to the bottom, as issuers may prefer countries with loose regulations over countries with stricter ones. Available evidence, however, does not support this proposition. On the contrary, there seems to be a strong trend to migrate to stricter regimes (Coffee, 1999a; Romano, 1998). As far as the insurance industry is concerned, interface jurisdiction makes a strong case for harmonization. In both cases, however, the efficacy of harmonized rules will depend to a large extent on the ability of different countries to enforce them. To the extent issuers wish to migrate to weak regulatory regimes, weaknesses in enforcement can create incentives for migration similar to weak laws on the books.

The development of best principles for corporate governance could be justified on the grounds that political economies of scale can be used to justify legal harmonization in this area of law (Leebron, 1996, note 4: 63). Changes in the existing corporate governance regime may be difficult due to political stalemate. This problem could be solved by shifting jurisdiction to a supranational body, or by providing principles from the outside. However, the enforcement of legal standards thus introduced depends on substantial domestic support as well as additional institutional change, and the supply of legal standards may not be sufficient to accomplish this. A second argument in favour of standardizing principles of corporate governance could be that they prevent governments from adopting rules that clearly serve only some interests, thus making these rules more transparent (Leebron, 1996, note 4: 65). On the downside, however, standardization reduces the choices for domestic law makers in developing their own legal solutions, which might be a better fit for the problems they face, or for the institutional capacities they have. Moreover, the harmonization of standards still leaves ample room for ambiguity when translating them into specific domestic rules, and is no guarantee for the standards being enforced in practice.

Thus, although there are good justifications for harmonization, at least in some of the areas of the law mentioned, the test for the success of harmonization efforts will be the enforcement of the new laws. This leads us to the basic proposition of this paper: Even if it were possible to design the perfect law or to develop the best standards for a particular area of the law, the incorporation of this law into a domestic legal system is per se not a guarantee for it to become effective. For the latter, the process of law-making, the compatibility of the new rules with pre-existing ones as well as with given economic and political conditions, and the existence of constituencies with a demand for these rules is more important than the contents of the supplied rules.

In the end, this argument favours decentralized law-making and, by implication, regulatory competition over harmonization. But the point is not that regulatory competition consistently produces superior law, but that it produces law in a way that its relevance will be understood domestically and that innovations and adaptations will take place endogenously through the process of socio-economic and political change.

\section{The interdependence of rules}

The purpose of standardizing legal rules is to achieve conformity in the contents and quality of law across different countries. Additional expectations are usually associated with the standardization of law, 
including lowering transaction costs for market participants, improving the quality of legal institutions in some countries, and ensuring consistency in the application, interpretation and enforcement of the law. This chapter demonstrates that even the primary purpose of standardizing legal rules - conformity in the contents of law across countries - is difficult to achieve. The reason is that only very few rules are free- standing and do not require further explanation in the form of explicit or implicit references to other rules, legal terms or concepts. In principle, the more explanations or cross-references a rule requires, the more difficult it is to achieve conformity.

A good example for free-standing rules are most, although not all, traffic rules. The rule that a car comes to a stop at an intersection does not require further explanation. The use of traffic signals is a means to facilitate the recognition of this rule in different countries, but adds nothing to the rule itself. We shall ignore the possibility that this rule is enforced differently in different countries (i.e. in some the police may not intervene when cars slow down rather than bringing the vehicle to a complete stop, while in others they may insist on a full stop). The point is that no further references to other legal rules or concepts are needed to convey the full contents and meaning of the rule (although different enforcement practices may change its meaning over time). Some traffic rules require, if not a reference to other legal concepts, at least clarification. An example is speed limits that apply only under certain conditions, i.e. when the road is wet, in foggy weather, etc. Courts in most countries have had to clarify the threshold for "wetness" or "fog". This creates the possibility for diverging contents of seemingly identical rules. In some countries, a road is said to be wet only once a seamless layer of water has formed, while in others a few drops of rain may suffice.

More complexity is added when a rule is not free-standing but its meaning can be understood only in conjunction with other legal concepts. We call these "dependent rules". A simple example of a dependent rule is "do not steal". The critical term is "stealing". An example for defining stealing taken from the German criminal code is "the taking of an alien object by breaching someone else's possession". A host of further questions arises from this definition, and real world cases demonstrate that the application of the very simple rule "do not steal" does in fact raise questions, such as what is an object? Does it include electricity or gas? For example, is it stealing if somebody hooks his home to an electricity line without contract and payment? What is alien?
Only objects that are clearly owned by somebody else, or also those the "offender" co-owns, or those that are part of a common pool? What is a breach of possession? What happens if the original owner has "lost" his property?

If we want to standardize the rule "do not steal" as a legal one that will be consistently applied across different jurisdictions, we need to agree on some of the basic concepts behind this rule. Otherwise standardization will remain at the surface of very diverse legal concepts that give a different meaning to identical rules when applied in different contents. This suggests that the standardized rule must include referenced legal concepts. There are several possible ways to go about this. First, one can use the concepts of a particular national legal order. Second, one can try to find the lowest common denominator of the diverse legal concepts that are in use in the jurisdictions that participate in the standardization effort. And, third, one can try to create new concepts that synthesize different legal concepts. The three approaches have different tradeoffs, which are discussed below.

\section{A. National model}

The choice of a particular national legal order may reduce the costs of adaptation, as at least one country already complies with the new standards. However, at least if adopted by States, this approach smells of domination, or legal imperialism. Political reasons therefore make it unlikely that this approach is taken openly, although the search for common denominators or a new synthesis often disguises the influence of a particular national legal order. Political factors should be taken seriously, not only because they may delay or dwarf the standardization effort, but because they will have a strong impact on reception of the standardized rule. If a legal standard is rejected for political reasons, it is unlikely that substantial efforts will be made to enforce it. But there are also other reasons for questioning the efficacy of this approach for legal standardization. Most importantly, foreign national concepts may be inconsistent with the pre-existing legal and social concepts in the law-receiving country. Several outcomes may result from this mismatch of new and old concepts. First, the new concept may come to dominate over time and replace pre-existing ones. This would lead to convergence of law as a result of standardization. Second, new and old concepts may coexist with each other. This leads to a segmentation of the legal order 
and reduces rather than increases certainty, because the jurisdiction of different bodies of case law, their relation to other legal rules, as well as their contents, will need to be determined on a case-by-case basis. Third, the new legal concept might be ignored and leave no traces on the domestic legal order, even though it is on the books. Only in the first case can it be expected that the introduction of standardization will generate the desired effects, but ex ante this outcome is undetermined. A different question is whether companies opt for foreign legal systems for individual transactions. Choice of law as well as choice of forum (the place where disputes should be abjudicated) clauses are common in transnational contracts, and frequently parties choose a jurisdiction that is not the home jurisdiction of either party. The choice of a particular legal system may entail additional costs as transactions have to be tailor-made to it, and lawyers with specific knowledge of that system need to be hired. However, having a fall-back option for issues the contract does not cover and referring to a system that is known to be highly developed and fairly consistent may well be worth the price.

\section{B. Lowest cost denominator}

The lowest common denominator (LCD) approach is frequently used for standardizing the law. It avoids some of the problems of choosing a particular legal order because, at least in theory, the LCD should be compatible with pre-existing concepts and rules. However, this approach limits the scope of standardization. The minimum standards that are established do not preclude diversity in different jurisdictions. On the positive side, they may raise the level of legal rules in countries whose pre-standardization laws did not meet the minimum standard. On the negative, they may lower the level of legal standards in jurisdictions that had already developed higher standards. This does not necessarily prevent a country from raising its national standards, but market forces may force regulators to stick to the common denominator. Moreover, raising standards may be prevented by other rules of international or regional trade, as they could be interpreted as entry barriers in disguise which violate the principle of free trade. Recent trade disputes between the European Union and the United States about the export of beef meat treated with hormones exemplify different priorities concerning consumer protection versus free trade. European Union case law is full of examples that show the difficulties in balancing the goal of creat- ing a common legal framework for the European market on the one hand, and, on the other, national governments seeking to ascertain their prerogative over areas of the law that for various reasons are deemed to be of "national interest". Similar conflicts can be expected for other standardization efforts, and should be taken into consideration when determining the areas and scope of standardized law. ${ }^{21}$

\section{Synthetic concept}

A compromise between these two approaches is to create a new legal concept based on comparative research and to incorporate it into the standardized rule. This approach is appealing because it avoids, or at least mitigates, some of the political problems of using a particular national legal order, mentioned above. It can also be regarded as an improvement to the LCD approach because it raises the level of the standardized rule beyond this minimum level, and thus reduces the likelihood that some countries will see the need for more stringent national regulation. Yet, as with all compromises, some of the problems outlined for the national model and the LCD approach remain. For example, there is little guarantee that the synthesis will be a better match for pre-existing legal institutions than foreign national solution. Moreover, the coalition of countries that pushes through the synthesis may be met with similar political resistance as the choice of a national model. In comparison to the LCD approach, the level of the standardized rule may be higher, but not substantially, as a synthesis is based on a compromise. In addition, new problems arise. Most importantly, the new synthetic concept is, as the name implies, an artificial product that has not been tested in any legal system. The new concepts will need to be clarified in future case law. Judges and other law enforcers in the different jurisdictions lack a common point of reference to interpret these concepts, and this increases uncertainty for the end users of the law. It is therefore not surprising to find that they frequently opt out of internationally standardized rules and prefer to choose a specific legal order to govern their transactions. An example is the Vienna Convention on the International Sale of Goods (CISG). Available evidence suggests that in the few cases where courts have applied the Convention, both parties were apparently unaware that this Convention governed their transaction (Walt, 1999). Parties realizing that they might be subjected to it frequently opt out of it by including a provision in the contract that explicitly denies the application of the CISG. ${ }^{22}$ The reason 
for opting out is that the uncertainties involved in interpreting the new terms and concepts included in the Convention are deemed to be too high (Walt, 1999) ${ }^{23}$ By contrast, where standardization is based on an existing national model, that national legal system may be used as a reference point for further clarifications. And where the LCD approach is used, judges may resort to comparative research to identify and interpret legal concepts referenced in the law. Newly created synthetic concepts, by contrast, need to be interpreted from scratch. Legal experts who helped to design them may participate in this process, but this raises the spectre of making future legal development dependent on a small group of more or less arbitrarily chosen experts. It may also create moral hazard problems, as experts may try to ensure that their services will be needed in the future when designing the standardized rules in the first place (Schwartz and Scott, 1995).

\section{Law as a cognitive institution}

The interdependence of legal rules and the characteristic of law as a "cognitive institution" are closely related. ${ }^{24}$ Because most rules are not freestanding, they can be understood only in the context of a given legal order. Information about the existence of a norm and its contents is a prerequisite for any impact of the law beyond a shelf life. This problem can be overcome by improving legal information systems. ${ }^{25}$ An additional requirement is that legal rules be understood. This is a serious constraint for legal transplantation, because - as Sunstein put it "the meaning of legal statements is a function of social norms, not of the speaker's intentions" (Sunstein, 1996a: 2050). ${ }^{26}$ In other words, however perfectly designed a law that is supplied from the outside may be, its impact is ultimately determined by how it is understood by law makers, law enforcers, and law users at the receiving end.

Assuming that a cognitive gap exists between any rule that is supplied and the understanding of that rule by its end-users, and that this gap impedes the effectiveness of transplanted rules, the question arises as to how to close this gap. One approach taken in the literature is to make appropriate changes on the supply side, for example by supplying simple, bright-line rules rather than detailed complex ones. ${ }^{27}$ An alternative approach is for the law to spell out in detail the rights and responsibilities of the relevant parties. This is supposed to have beneficial educative effects on the recipients of the law. ${ }^{28} \mathrm{~A}$ bright line approach could be sufficient if the problem was merely an intellectual, not a cognitive, one. It is possible to argue that in many countries the legal profession is not sufficiently trained and highly sophisticated rules may not be understood for this reason. However, it is also true that even the simplest rule acquires different meanings in different contexts. Take, for example, the simple rule "do not steal", we have discussed above. How should this rule be applied in relation to communal property? Is overgrazing of the commons captured? Where shall the line between normal use and overgrazing be drawn? What about takings by people who are not members of the social group which shares the commons? As discussed in the previous chapter, it is possible to define the concepts that the rule "do not steal" refers to in more detail. This will certainly clarify the scope of application of this rule, but it may also render the rule useless in contexts that are outside its scope.

\section{Law enforcement}

The idea behind the standardization of law is that well-designed legal standards once adopted by domestic governments will change the behaviour of individuals and entities, and thereby influence the path of future economic development. The adoption of a law, however, is not a guarantee that it will indeed affect behaviour, or that it will affect behaviour in the intended fashion. While informal rules of behaviour, or norms, survive only if a sufficiently large number of people comply with them, formal law may remain on the books, even if ignored or contradicted by actual behaviour.

The enactment of a new law that is designed to change behaviour can have essentially four outcomes. First, the law may be ignored. Existing behavioural patterns are not changed and, as a result, the law does not have any impact. Second, the law may be observed formally, but be circumvented in practice. This has been aptly called "creative compliance" ${ }^{29}$ Creative compliance is relatively easy, where the new law is ill-specified and general terms leave much room to interpretation. The scope of behaviour that can be subsumed under such a law is broad. Courts typically try to define the limits of such expansive interpretation by taking recourse to the spirit of the law or the intention of the law makers. These concepts, however, are themselves unspecified and subject to varying interpretations. Creative compliance is also possible when rules are highly specified. 
In fact, McBarnet and Whelan, who coined this term, have defined it as "the use of formalism to avoid legal control" (Belcher, 1995). Formalistic application of the law often contradicts its spirit. Examples include the holding of elections to buttress the claim that a country is a democracy, even though only incumbents may stand for office; the convocation of a shareholder meeting at a remote place, which only pre-informed shareholders are able to reach on time; or the exclusion of critical shareholders under the guise of formalistic violations of the law. ${ }^{30}$

Third, law may be designed so that it applies only selectively. Examples for explicit exemptions include a waiver of strict liability rules, and the implementation of safety or environmental standards for certain sectors. Frequently, however, exemptions are implicit. An exemption from the application of an otherwise general rule can be granted by defining the scope of its application in a fashion that excludes potential target groups, which may render the entire rule ineffective. An example is a provision in the German corporate law that denies liability of management for wrongful conduct if the conduct was approved by a majority vote taken at a shareholder meeting. Since German companies are often controlled by friendly blockholders, such a vote may not be difficult to come by. The provision in essence exempts management from liability vis-à-vis minority shareholders. ${ }^{31}$ Even when a law applies universally, enforcement may be selective. In tax matters States may wish to spare sectors that are key to the economy and/or have good political connections. Finally, the fourth and - from the standpoint of law makers - most desirable outcome is that the new law may be used and applied indiscriminately in the intended fashion.

The propensity of the law to affect behaviour differs in the four scenarios. A law ignored has no impact on actual behaviour. A law that leads to creative compliance has an impact on behaviour, but not the intended one. The expected effect of the law is typically not achieved. Instead, economic agents devise schemes to neutralize its impact. The net result may well be a welfare loss, as the circumvention strategies may create additional costs. The selective application of law does change the behaviour of those who either voluntarily comply with, or are subjected to (selective) enforcement. The selectivity of law enforcement may over time erode the force of the law and lead to widespread creative rather than true compliance. This will be the case when those who bear the costs of compliance cannot reap its benefits, because they will accrue only if a sufficiently large number of other agents comply as well. An example is compliance with disclosure requirements. Even though this is costly for firms, they may benefit from comparing their information with that of other market participants and from reading the market responses to the disclosed information. However, these benefits accrue only if a firm is not alone in disclosing its information.

When voluntary compliance cannot be ensured, to be effective law has to be enforced by the State. One may regard voluntary compliance and State enforcement as substitutes. In fact, they are complements. To be effective State enforcement depends on high levels of voluntary compliance. Only in this case can resources be bundled to enforce the law against deviant behaviour. If deviant behaviour is widespread, law enforcement will be ineffective. The reverse is also true. Thus, the fact that most disputes in every day life are solved without reverting to State enforcement agencies is, at least in part, dependent on the belief that, if this failed, State enforcement would in fact be available.

\section{Standardizing law for the international financial architecture}

In this chapter, we apply the above analysis to those legal rules that currently form the core of the standardization efforts endorsed by the IMF (see chapter II above). We shall exclude the UNCITRAL Model law on cross-border insolvency, because the target of this model law is limited to transnational cases and the improvement of domestic legal institutions is not the primary purpose of this harmonization effort.

The purpose of this analysis is to establish whether the incorporation of the standardized rules are likely to lead to an improvement in the domestic legal system or not. This would require, first, that the standards be used for assessing the quality of the domestic legal framework. In other words, the standards should offer independent guidance, which implies that key concepts are included in the standards themselves. Second, we shall check the extent to which the major standardized rules are free-standing, or else whether they are dependent on domestic or synthetic legal concepts. Free-standing rules will be the easiest to incorporate, as they do not require extensive additional reform efforts to make pre-existing rules compatible with them. Reference to domestic systems may increase the likelihood that a standard will be used and applied in future, as well as questions as to whether the overall goal of the standardization effort can be achieved. References 
to synthetic concepts incorporated in the standards (or related documents) will achieve the harmonization of the law on the books, but as discussed above, they may be difficult to interpret and enforce.

\section{A. International Accounting Standards}

Of the different legal standards discussed in this paper, only the International Accounting Standards are free-standing. The immediate objective of these standards is to formulate an independent set of accounting standards for worldwide use by companies (IASC, 1999, note 41: 29). The harmonization of accounting standards around the world is a second objective, but this is not a prerequisite for the first objective to be realized. In essence, IAS can be compared to the artificial language Esperanto. Esperanto does not replace local languages, but functions as an independent medium for communication. While Esperanto has not been a success, there is evidence that firms in many jurisdictions have decided to disclose their financial data both according to domestic standards and according to IAS. This is costly for companies and a good reason to harmonize the rules over time. But the goal of IAS can be achieved irrespective of harmonization, as they offer an additional set of standards that facilitates international comparisons. In order to create a free-standing body of rules, the IAS include principles of accounting, its purposes, as well as detailed rules about how to enter information for specific items, including inventories, costs for research and development, employee benefits, and the like. It is certainly possible (and indeed quite likely) that not everything of relevance is included, i.e. that IAS have gaps. But this feature they share with any domestic legal rule. The difference to dependent rules is that the meaning of the IAS can be derived from reading the IAS alone and no further reference to other rules, legal concepts or entire bodies of law needs to be made. In the light of the above analysis, this bodes well for harmonization. Although domestic law makers may, for whatever reasons, stick to their own accounting standards, firms have at least the option to use IAS in addition to the local ones. This might be costly, but the rewards in the form of greater recognition on the international market may well be worth it.

\section{B. IOSCO Objectives and Principles of Securities Legislation $^{32}$}

The IOSCO Objectives and Principles of Securities Legislation (IOSCO Principles) include only the basic principles of securities legislation and refer to a host of other guidelines and recommendations that were developed by IOSCO. We shall ignore most of these other guidelines for the purpose of this analysis, although it should be noted that they often provide the concepts that the general guidelines discussed here refer to.

The IOSCO Principles explicitly state that the efficacy of the proposed rules will depend on the scope and quality of the general framework for commercial law. Thus, they are making these rules dependent not only on specific rules included in other statutes, but on the broader legal framework. Annex 3 to the IOSCO Principles lists those parts of the legal framework which, according to IOSCO, are of special importance. The list includes company, commercial, and contract law; tax laws; bankruptcy and insolvency laws; competition law; banking law; and the entire system for dispute resolution. For each area of the law, IOSCO lists those aspects that are of particular relevance to securities regulation. With respect to company law, special company formation, the duties of directors and officers, regulations of takeover bids and other transactions intended to effect a change in control, laws governing the issue and offer for sale of securities, disclosure of information to security holders to enable informed voting decisions and disclosure of material shareholders are listed. For commercial and contract law, the IOSCO Principles include private rights of contract, facilitation of securities lending and hypothecation, property rights, including rights attaching to securities, and the rules governing the transfer of those rights. For other areas, the reference is more opaque. With respect to tax laws, the Principles note the importance of clarity and consistency, "including, but not limited to, the treatment of investments and investment products". And for dispute resolution systems, "a fair and efficient judicial system (including the alternative of arbitration or other alternative dispute resolution mechanisms)" as well as the "enforceability of court orders and arbitration awards, including foreign orders and awards" are noted as prerequisites for effective securities regulation. In sum, securities legislation rests on the existence of a comprehensive and effective legal system.

Without questioning the interdependence of securities legislation with other parts of the legal system, it is at least worth considering whether effective securities legislation could serve as a functional substitute to other legal provisions that may not be working quite as well. The concept of a functional substitute is well known in comparative law, 
where scholars have long asserted that identical legal problems may be solved by different legal rules and/or institutions. ${ }^{33}$ A simple example is the treatment of trusts as a contract or a property right. Economic analysis of the details of these legal concepts in civil and common law systems reveals that, irrespective of this fundamental difference, they perform essentially similar functions (Hansmann and Mattei, 1995). One proposition made in the comparative corporate governance literature - of particular relevance to the questions addressed in this paper is that weak enforcement of minority shareholder rights in the general court system could be substituted by effective securities market legislation. ${ }^{34}$ The successful migration of firms from home markets that protect shareholder rights only weakly to markets with strong securities regulations is taken as an indication for the host jurisdiction offering substitute legal protection. The interesting point about this example is that migrating companies take the home corporate law with them, but subject themselves to more stringent securities regulations. Observers of capital market development in transition economies have found that effective securities market regulation has been more important in promoting market development than minority shareholder protection. ${ }^{35}$ Results from a study using data from 24 transition economies confirm these findings. In fact, the quality of securities market legislation is the only law on the books variable that has a (marginally) significant impact on securities market development in these countries.

The major lesson from these findings is that despite the fact that IOSCO itself draws attention to other parts of the legal system as a prerequisite for the efficacy of the proposed standards, it is at least worth considering whether strong securities market regulations could substitute for weaknesses in other areas. Yet, it is important to consider the tradeoffs of investing in one part of the legal system with limited impact on others when resources for legal reform are limited.

Beyond a general reference to other areas of the domestic legal system, the IOSCO Principles explicitly reference three types of rules: (i) specific domestic legislation; (ii) domestic politics and the accountability of government agents; and (iii) synthetic legal concepts developed in other IOSCO regulations. The very fact that they do so demonstrates the breadth and complexity of legal reform that will be necessary to make securities legislation work. In addition, the examples show that in the end domestic law makers are in many cases left to decide for themselves the appropriate level of regulations.

References to domestic legislation include the use of legal concepts that imply further definitions. An example is the problem of conflict of interests that, according to IOSCO Principles, is relevant, in particular for self-governing organizations and managers of collective investment schemes (CIS). ${ }^{36}$ Where the boundaries are to be drawn between permissible actions and those that are clearly considered a conflict of interests is up to each legal system. In most countries, the final demarcation of this line is left to the courts, as it is difficult to come up with a definition for codifying a rule that is both sufficiently abstract to include a range of potential cases and yet still specific enough to be enforceable. Other examples include more general references to regulations, including accounting standards, the regulation of CIS, intermediaries, or banks. ${ }^{37}$ Further guidance is given in some additional IOSCO guidelines. However, in several instances, regulators are warned that a particular issue needs to be regulated, but no guidance as to the possible contents is given. The IOSCO Principles state, for example, that the level of disclosure required for corporate control differs from jurisdiction to jurisdiction. ${ }^{38}$ While this statement is certainly true, it is of little guidance for law makers in developing markets in deciding on an appropriate level of disclosure for their country. ${ }^{39}$

In several instances, the IOSCO Principles go far beyond references to specific parts of the domestic legal system, but reference the quality of the overall legal system, or the legal and political governance system. In an attempt to define the meaning of "accountability of the regulator", the Principles state that this implies:

- a regulator that operates independently of sectoral interests;

- a system of public accountability of the regulator;

- a system permitting judicial review of the regulator's decisions.

These are important conditions, which point directly to the political structure and the realization of the rule of law in a given country. A system permitting judicial review of decisions of the regulator certainly does not imply that all acts of the State need to be subject to judicial review, but certainly those of the securities market regulator. The issue of public accountability of the regulator raises a host of questions about the effectiveness of legal constraints 
and other mechanisms of accountability, including appointment, dismissal and disciplinary procedures. Taken seriously, making the securities market regulator accountable would in many countries require far-reaching political reforms.

Finally, in a few cases, the IOSCO Principles reference synthetic legal concepts. An example is the reference to regulation of collective investment schemes (CIS). IOSCO has adopted separate guidelines for CIS which include a definition of this term. ${ }^{40}$ It is quite comprehensive and tries to include the variance of investment funds that deal in securities found in a large number of countries (or at least those that were most influential in drafting the guideline). At the same time, it is limited by excluding closedend funds and "schemes investing in property/real estate, mortgages or venture capital". ${ }^{41}$ There are two problems with this approach. First, the definition of what comprises a collective investment scheme is based on partial empirical observation. It is derived from investment schemes common in developed markets, but is likely to exclude many other structures that already exist or may arise in other markets. Second, the regulation of one class of investment (open-ended funds that invest in securities), but not others, can create distortions. Promoters of schemes that fall under the definition of the guideline will certainly try to find ways around them when confronted with adjustment and compliance costs.

To summarize, the IOSCO Principles cannot be characterized as free-standing rules. They reference other laws and legal concepts, including domestic laws and synthetic concepts found in other IOSCO Principles. In addition, they call attention to how closely related a well-functioning regime for regulating securities market is with the political system and the existence of absence of mechanisms of accountability. A general agreement to adopt these standards and comply with them can therefore be hardly more than a memorandum of understanding. Without additional reforms, including reforms aimed at enhancing the accountability of State agents, change will not be achieved.

\section{IAIS Insurance Principles, Standards and Guidance Papers ${ }^{42}$}

The most striking aspect about the IAIS Insurance Principles, Standards and Guidance Papers (IAIS Principles) is that they fail to define what constitutes an insurance business. The introduction to the Principles explicitly refers this to future work. In lieu of a common definition of insurance business, the Principles leave the definition of insurance business entirely to domestic law. This, of course, is not only an open invitation to creative compliance, ${ }^{43}$ but defeats the very purpose of legal harmonization. Thus, the IAIS Principles fail to meet the first criterion we established at the outset of this analysis, namely that standards can be used to assess the quality of the domestic legal framework.

The inability to find a common definition can in part be attributed to the wide variety of risks that may be insured against, which distinguishes this sector from other financial industries. It certainly reflects the diversity of insurance activities in IAIS member countries and the difficulties in reconciling differences in commercial practice and regulatory activities of different countries. This of course raises the more fundamental question whether standardization in such a diverse sector is at all meaningful. It is probably safe to say that until a common definition of what constitutes an insurance business is agreed upon, the Principles are unlikely to have any serious impact. Take, for example, the general licensing principles established by IAIS. The basic notion is that companies wishing to underwrite insurance in the domestic insurance market should be licensed (IAIS Principles: 5). However absent a definition of what insurance business means, it is simply impossible to determine whether or not countries comply with the licensing requirement. A provision that states that "licence refers to the authority to operate business in the domestic market, which under domestic law is defined as insurance business" (IAIS Principles: $30(5))$ is as meaningless as a provision that would allocate the right to define the scope of legal protection of trade marks to their users. The Principles recognize that differences in the definition of insurance business can lead to supervisory problems, especially where cross-border operations are concerned (IAIS Principles: 31 (13)). Yet, they contemplate excluding certain activities from the application of the IAIS Principles - without having established the scope of their applicability in the first place. Thus, insurance activities that are limited as to the possible number of policyholders or to a geographical area shall be exempted from the application of the Principles. The phrasing of the exemption suggests that the drafters of the Principles had to bow to pressure from members in whose countries non-licensed insurance activities proliferate: "The reason for this fact [the exclusion] could be that the insured sums do not exceed certain amounts, or that losses are compensated by payments in kind, and that the activities are pursued following the idea of solidar- 
ity". It is not difficult to imagine how non-licensed insurance activities could mushroom under the pretext that they pursue the idea of solidarity. More importantly, to include exemptions in regulations that do not define the scope of the regulation is a meaningless exercise. Without clearly stating whether the criteria used to justify the exclusions (number of policyholders, sums involved, purpose or motivation of activity) are relevant for defining the scope of insurance business regulations, they can hardly be used for justifying an exemption from their application.

Given that the IAIS Principles fail to provide even a common lowest denominator for the type of activities that will be governed by these principles, what can possibly be accomplished by the new standards? They establish a number of procedural requirements for setting up and licensing insurance businesses as well as for the withdrawal of the licence. These include provisions on the type of information that should be submitted when applying for a licence; an ultra vires provision that activities outside the approved scope of business are not permissible; minimum capital requirements; the submission of a business plan; as well as detailed information about the members of the board of directors, including professional education, training, and past employment (IAIS Principles: 33). But without a clear demarcation of the types of activities that should be subject to these requirements, they are only checklists for a possible scope of regulation, which can be determined only once we know what an insurance business is.

\section{OECD Principles on Corporate Governance $^{44}$}

Whereas the IOSCO and IAIS Principles can be characterized as a combination of LCD approaches to legal reform with some attempts to establish synthetic concepts, the OECD Principles on Corporate Governance (OECD CG Principles) take a more radical approach. They use economic rationales as a normative agenda and deduce specific rules for shareholder protection. ${ }^{45}$ The principles establish the concept of "basic shareholder rights" and explain this with the statement that "equity investors have certain property rights" (OECD CG Principles: 12). In other words, the essence of equity investment is the acquisition of property rights and the OECD CG Principles derive the basic shareholder rights from applying the property rights concept to a publicly traded firm. Yet, the CG Principles raise similar ques- tions as to their precise meaning and the scope of their application as do the IOSCO or IAIS Principles. The CG Principles state that "basic" shareholder rights include the right to:

- $\quad$ secure methods of ownership registration;

- convey or transfer shares;

- obtain relevant information on the corporation on a timely and regular basis;

- participate and vote in general shareholder meetings;

- $\quad$ elect members of the board;

- $\quad$ share in the profits of the corporation.

Each of these rights requires further explanation, i.e.:

- When are methods of ownership registration secured?

- Is the right to convey or transfer shares violated if the transfer is subjected to approval by other shareholders and/or the board of directors?

- What is relevant information?

Some guidance is given in the Annotations to the CG Principles for answering these questions, but the task of translating the principles into specific laws and interpreting their meaning is left to domestic law makers and law enforcers.

The advantage of standards that are derived from abstract principles rather than consisting merely of a synthesis of existing legislation is that they offer standards for assessing the quality of the law in different countries. The disadvantage is that the principles from which they are derived may have little to do with existing practice, and the remedies they offer could therefore be quite ineffective. In particular, the CG Principles "focus on governance problems that result from the separation of ownership and control" (OECD CG Principles: 2). This certainly reflects the classic paradigm within the corporate governance literature. ${ }^{46}$ Yet, an increasing number of empirical studies suggest that in most countries the separation of ownership and control is not the key issue. Concentrated ownership is much more common than had earlier been assumed (La Porta et al., 1998, 1999). Where a controlling shareholder is present, however, ownership and control is not separated. Different problems may arise in this situation, which may require different legal solutions. The protection of minority shareholders against blockholders, for example, will be more important than protecting 
minority shareholders against management, as management is effectively controlled by a blockholder. Even if the blockholder is only a disguise for de factor managerial control, the target of the rules should probably be the blockholder, rather than management.

An example for how misleading the CG Principles may be when analysed in the light of real world corporate governance problems, particularly in emerging markets, is their treatment of "stakeholders". This term loosely refers to all parties with a stake in the firm that are not shareholders and includes investors, employees, creditors and suppliers (CG Principles, Annotations: 18). The only guidance as to how to handle the interests of these various stakeholders is that "where stakeholder interests are protected by law, stakeholders should have the opportunity to obtain effective redress for violation of their rights". And the annotations add that "the legal framework and process should be transparent and not impede the ability of stakeholders to communicate and to obtain redress for the violation of rights".

It is difficult to apply these general statements to real world cases and figure out what the appropriate legal response to such cases could be. The most straightforward case is employee codetermination. Where the law gives employees the right to participate in the company's board and to vote on issues of business strategy, these rights should be enforced. Interestingly, the OECD CG Principles are silent on whether codetermination is desirable and fail to address the potential conflict between shareholder property rights and the legal rights allocated to employees under such a scheme. For all other stakeholders, the rights that could possibly be protected by law and should therefore be enforced are ambiguous.

Take, for example, the family-controlled foundation, which is only a subsidiary of, say, a chaebol in the Republic of Korea, and holds only a minority stake in the parent company. Yet, this foundation controls key business decisions and, in particular, the process of nominating and electing the chief executive officer of the parent company, who may be, but does not need to be, a member of the family. ${ }^{47}$ Is this foundation a "stakeholder"? What legally protected rights does it have and what is the meaning of an unrestricted right to communicate among stakeholders in an environment where deals among different members of the controlling family are common place? Another example is the influential role a local government might have on corporations that are located within its jurisdiction. Is the government a stakeholder? If yes, the wording of the OECD Principles could be interpreted restrictively to mean that only those rights that are protected by law should be respected. This could be used by a corporation to defend its interests against political interference. But certainly there will be provisions in the local constitution that give the government the right to take appropriate measures to enhance the public good. Are these legally protected rights?

These examples demonstrate that the attempt to derive specific rules from economic "truths" is not without flaws. The solutions thus arrived at are meaningful only if the theoretical assumptions about the main corporate governance problems are consistent with reality. To the extent this is not the case, they offer little guidance to law makers for solving real world problems.

\section{Implications for developing countries}

This chapter addresses the question of what implications the adoption of the above legal standards may have for the propensity of countries, in particular developing countries, to attract foreign investors and to participate in global markets. At the outset, three points are worth stating. First, harmonization or standardization of law is not necessary for international trade and investment to take place. Most transactions today take place using law that has not been harmonized or standardized. Second, the areas of the law that are at the core of the IMF standardization claims are important for attracting financial investors, in particular portfolio investors. Their relevance to foreign direct investment, however, is less evident. Analyses of the flow of foreign investments and data from surveys of investors around the world clearly show that a functioning legal system for contract enforcement and effective legal constraints that limit arbitrary State power are important determinants for investment decisions (WEF, 2000). While this does not mean that improvements in financial market legislation are not important, countries with limited resources available for law reform clearly need to make a choice and target their reform efforts to areas that will bring the highest returns. Third, the adoption of legal standards in any area of the law, including financial law, is not sufficient for creating an effective institutional framework to enhance a country's ability to attract foreign investment or create effective buffers against the contagion effects of a future crisis. The third point requires further explanation. 
The underwriting of international standards for the said areas of the law may serve as a signal to foreign investors that a country is indeed complying with these standards. Past experience shows that once a crisis hits, investors will pull out where they might have serious doubts about the effectiveness of legal institutions and their ability to protect their claims. At this point, they will not be misled by formal indicators, but take a closer look at the ability of countries to actually enforce these rules. Improvements in the legal infrastructure can serve as a buffer against such swings, but only if this infrastructure is perceived to be effective.

The signalling function of internationally agreed legal standards is likely to erode if too many countries practice formal compliance, rather than real compliance. The question is not whether or not foreign investors will find out how effective legal institutions are, but only when. This creates a dilemma for countries intending not only to adopt international standards, but also to engage in further reforms. Because institutional reforms are generally slow, their payoffs will take some time to materialize. In the meantime the positive signal that adoption of the standard may have originally sent is likely to be undermined by crises in economies that have pursued merely a formal compliance strategy. Investments in extended legal reforms may be lost. Indeed the credibility of international legal standards could well be undermined.

The best strategy to counter this downward slope seems to be for countries not only to signal the adoption of formal legal standards, but also to ensure that they have the capacity to enforce the newly adopted laws and in fact to demonstrate this capacity. A selective approach to legal reforms tied in with institutional reforms and the allocation of sufficient resources to ensure their success would be a promising strategy. Successful reforms will re-enforce each other. Effective enforcement of new laws will enhance the credibility of legal institutions and raise investors' confidence in financial markets. This will also attract investors willing to make long- term commitments. By contrast, the best laws on the books may have little impact on the development of financial markets and their credibility in the eyes of domestic or foreign investors. A recent study that investigates the relation between legal reforms and financial market development in transition economies demonstrates this point. The substantial improvements in the law on the books as measured by a variety of legal indicators by and large have had little impact on the development of capital markets.
By contrast, the effectiveness of legal institutions had a much higher correlation with increases in market capitalization and improvements in liquidity (Pistor et al.,1999). ${ }^{48}$

Thus, the key to success for any given country will be the establishment of effective legal institutions. In part, this depends on the resources that are available, including financial and human resources. Where these resources are not available, or other obstacles stand in the way of effectuating financial law, a country should consider whether it is ready to expose itself fully to the winds of international financial markets. ${ }^{49}$ Resources, however, are not the only consideration. In addition, the process of legal reform needs to ensure that a sufficiently large domestic constituency is engaged in this reform. As was pointed out in the previous chapter, the efficacy of law enforcement depends on the level of voluntary compliance, and this in turn depends on the support for law reform by local constituencies. Research on the propensity of countries to develop effective legal institutions suggests that a strong demand for law reform is more important for the long-term development of effective legal institutions than the quality of the laws on the books (Berkowitz et al., 2000). ${ }^{50}$ These results hold when controlling for today's levels of GDP per capita, suggesting that the effectiveness of legal institutions is not determined only by a country's wealth.

A key element for successful reforms is access to information on the scope of legal solutions that exist to tackle a particular problem and the conditions under which these solutions may or may not be enforceable. This information is not easily available. The proposed standards for reforming the financial architecture certainly do not provide it. Instead, they rely on ambiguous guidelines and extensive references to synthetic concepts, that are in need of further clarification.

In the light of these considerations, this paper argues that a new approach to reforming legal systems in developing countries and emerging markets is warranted. Instead of having legal standards developed by legal experts or professional interest groups, law makers around the world should be given access to alternative legal solutions found in living legal systems. This would enable domestic agents to identify problems and find solutions that are adequate and potentially effective, given the institutional constraints of their country.

Law makers in the Republic of Korea, for example, will want to know how other countries with 
large business groups solve the problem of protecting minority shareholders in these groups. Different jurisdictions have experimented with different approaches. Common law countries use takeover codes to protect shareholders in transactions that could dilute their previous holdings. They are less concerned with minority shareholders that have decided to keep their stakes, unless blockholders misuse their dominant role. Germany, by contrast, has developed a complex legal regime for business groups in an attempt to protect minority shareholders in companies belonging to business groups. The reason for these different approaches can be found in diverging policy choices in the process of company formation during industrialization. In the United States, strong antitrust rules prevented close contractual or equity relations between firms, and thereby promoted either full integration or separation. Germany, by contrast, allowed the formation of cartels and thus saw the emergence of groups of companies interconnected by equity holdings, and explicit or implicit contractual arrangements. ${ }^{51}$ Countries that have business groups may want to consider legal systems that have developed ex post controls, because they have already foregone preventing the emergence of such groups ex ante. By contrast, the OECD CG Principles focus on ex ante rather than on ex post controls (OECD CG Principles, Article 1.D).

Irrespective of their initial conditions, all countries should have access to information on how different legal systems create mechanisms of accountability for common problems. A case in point is board members failing to comply with their obligations. The OECD CG Principles include a list of responsibilities of the board. However, they do not offer solutions to the vexing question as to how members of the boards shall be incentivized to take these responsibilities seriously, and what redress shareholders should obtain against members who fail to live up to their legal duties. Legal solutions range from dismissal with or without cause, compensation plans as incentive devices, rules on frequency of board meetings, and the way to direct or derivative shareholder suits. Law makers in the receiving country will need to address these issues in order to design procedural devices, without which the law cannot be enforced. ${ }^{52}$

Similar points can be made for the other areas of the law discussed in this paper. In the absence of a common definition of insurance business under the IAIS Guidelines, it is crucial that countries obtain access to information on what constitutes insurance businesses in different countries, why some activities are included, and others excluded. It is commonly known that in legal matters "the devil lies in the details". These details are not included in the discussed standards. In fact, by definition broad legal standards avoid these details. The laws to be enacted by different countries, however, will need to be much more specific.

What is needed, therefore, is a market for information about the scope of legal solutions to solve comparable problems, including information on how these solutions are tied into the general legal framework and the enforcement institutions. This would allow law makers to consult not only the laws from developed market economies, but also those of neighbouring countries, or other transition economies. They could identify elements from different systems and use this to develop a legal product they understand, and can afford. Moreover, other constituencies - professional organizations, self-governing bodies - should have similar access to information that would put them in a position to participate in the debate on which solution might be the best suited to their country. Access to different domestic legal systems is currently impeded not only by language barriers, but also by the idiosyncrasies of different legal systems. This makes it often difficult to locate the legal rules that address a particular problem, and to understand their links to other parts of the system. These problems are exacerbated by legal terminology, which differs from jurisdiction to jurisdiction.

Yet, it is not impossible to overcome these barriers. Japanese law makers in the late nineteenth century were able to debate in detail on whether the French, German, or English common law system would be more appropriate for them. ${ }^{53}$ They received experts from Europe and sent delegations to various countries to learn about their economic and legal systems. Law makers throughout the world should have an easier task to obtain relevant information. Travel certainly has become more convenient. More important, however, information technology offers opportunities for making legal information available around the globe. In fact, a wealth of legal information is already available on the web. The greatest obstacle for accessing and using this information is language barriers and, perhaps even more importantly, differences in the structure of legal systems which make it difficult to locate the rules or relevant case law that deal with a particular problem. Different legal systems use different grammars for organizing their laws. However, these problems are not insurmountable, at least not if resources were made available for new legal information systems rather than being used for creating general standards. 


\section{Conclusion}

The objective of this paper was to assess the standardization efforts of financial laws that are currently under way. Because standardization is costly, the paper first analyses the possible justifications for standardizing different areas of the law, including cross-border insolvency cases, accounting standards, securities regulation, insurance regulations, and principles of corporate governance. While good arguments can be found to justify these standardization efforts, the likelihood of their having any beneficial impact hinges on additional factors. The new standards need to be fitted into domestic legal systems. Most of them are not free-standing, but their meaning and interpretation depends on pre-existing rules or rules that will still need to be established. As discussed above, the IOSCO principles are quite explicit about the interdependence of the proposed rules with domestic ones. In addition, the effectiveness of these rules will depend on the efficacy of enforcement institutions. Given this close relationship between most standardization efforts - the IAS being the only exception to this - and the comprehensiveness and effectiveness of the domestic legal system, the paper asks whether standardization is the best strategy for improving domestic legal institutions. It suggests that this is not the case. The reason is that the process of standardizing rules makes it necessary to either develop synthetic concepts to bridge differences between different legal cultures, or to agree to the LCD. Neither result offers clear-cut solutions for domestic law makers, economic agents as the law consumers, or law enforcers. Instead, they need to give meaning to these concepts by relating them to pre-existing legal concepts, or interpreting them from scratch. In some cases, the process of standardization defeats its very purpose. An example is the IAIS guidelines, which include a comprehensive reference to domestic legal systems for defining the object ("insurance activity") for which standardized rules are to be developed. On a more theoretical level, the paper argues that, to be effective, law needs to have local constituencies with a strong interest in and understanding of the laws. This is a prerequisite for the new laws to become part of the continuous process of legal change, without which the formal legal system will remain largely irrelevant. It is also important for ensuring high levels of voluntary compliance with the law, and thus for its effectiveness. In sum, the paper warns against viewing legal standards as a panacea for building effective legal systems around the world.
Notes

1 The use of the term "standards" should not be confused with quality and product standards as a regulatory tool. We use this term to refer to the nature of a legal rule, in particular the level of specificity. For details see below chapter IV. We use the terms standardization and harmonization interchangeably, but note that standardization is a weak form of harmonization. A strong form would require that detailed legal rules be unified across different jurisdictions. For a discussion of the cost and benefits of law development using legal standards versus legal rules, see Kaplow (1992).

2 One may, of course, take the view that the standards are an insurance device for foreign investors. If high-risk countries can be forced to adopt internationally accepted legal rules, foreign investors can no longer be blamed for misguided investment decisions. I would like to thank David Woodruff for this point.

3 On the distinction between normative and non-normative harmonization quests, see Leebron (1996: 50). He distinguishes between pure "non-normative harmonization claims", which are "neutral with regard to which rule should be chosen as the basis of harmonized rule", and "pure harmonization claims" that aim at implementing the same policies or rules in all countries. Most harmonization claims, according to (1996), contain non-normative and normative claims, i.e. they can be referred to as mixed claims.

4 The importance of effective legal institutions - i.e. those that are capable of enforcing existing rules and actually do this - has also been stressed by Cornford (1995).

5 For a more comprehensive analysis of the relation between financial market development and economic growth, see Goldsmith (1969: 561).

6 For a discussion of the 1988 standards and the proposals for their revision, see Cornford (2000).

7 This has become apparent in particular in regard to the Asian Financial Crisis. For an analysis of the quality of the legal framework as an explanatory variable for the extent to which different countries have been affected by the crisis, see Johnson et al. (1998). By contrast, Huang and $\mathrm{Xu}$ (1999) offer an analysis that focuses less on legal design, and more on the financial institutions in an environment with and without soft-budget constraint.

8 The agencies involved in these efforts and a short summary of the areas of the law standardized by them can be found at: http://www.imf.org/eternal/standards/agency.htm.

9 The Conventions include, among others, those on: the Limitation Period in the International Sale of Goods (New York, 1974/1980); the Carriage of Goods by Sea (Hamburg, 1978); Contracts for the International Sale of Goods (Vienna, 1980); International Bills of Exchange and International Promissory Notes (New York, 1988); and the Recognition and Enforcement of Foreign Arbitral Awards (New York, 1958). The Model laws include the UNCITRAL Model Law on International Commercial Arbitration (1985); on International Credit Transfers (1992); Procurement of Goods, Construction and Services (1994); and on Electronic Commerce (1996). For a detailed status report of the signature and ratification of the various conventions see website: http://www.uncitral. org/english/texts/ index.htm.

10 The IASC, for example, stresses the need for international harmonization in light of the huge costs created by the current multiplicity of accounting standards, and advo- 
cates the adoption of International Accounting Standards for developed as well as developing countries. See website: http://iasc.org.uk/frame/cen1_4.htm.

11 Art. 12 of the Guide to Enactment of the UNCITRAL Model Law on Cross-border Insolvency, for example, explicitly states that while countries are free to make any changes they see fit, ".. in order to achieve a satisfactory degree of harmonization and certainty, it is recommended that States make as few changes as possible in incorporating the model law into their legal systems".

12 Subscribing to legal standards as used in this paper does not imply any formal process of ratification. As noted above, most of the standards discussed in this paper are not mandatory. We use the term "subscribing" loosely to refer to any type of commitment a country makes to these standards, including public statements that they govern law reform efforts.

13 See Woodruff (1999) for a similar point relating to legal reforms in Russia.

14 The literature is voluminous and can only be partially referenced in this context. In the area of corporate law, Buxbaum and Hopt (1988) and Buxbaum et al. (1991) give an overview of the main arguments for and against harmonization. See also Romano (1993) and Bebchuk (1992). A similar debate is currently underway for securities legislation. See Romano (1998) for further references, as well as the contributions in Barfield (1996), and especially White (1996). An endorsement of the European harmonization strategy may be found in Warren (1990: 185). More cautiously based on an analysis of the achievements of harmonization are the contributions in Ferrarini (1998).

15 Compare Kamar (1998), who focuses on the purported superiority of the Delaware corporate law. For a more general argument see Gillette (1998).

16 See Schwartz and Scott (1995) for a detailed analysis of private law-making involving legal experts.

17 This is exemplified with the case of the Delaware corporate law by Kamar (1998:16).

18 A good example is the case of Nebraska, which copied the Delaware corporate statutes word by word, but was not able to attract corporations. This has been attributed to positive network externality of the Delaware system, which could be replicated. See Kamar (1998: 16).

19 Johnson (1998: note 8). The level of legal protection in this context refers to the quality of shareholder and creditor rights, as measured by La Porta (1998). The effectiveness of legal institutions refers to the assessment of the functioning of the judiciary, the ability to enforce contracts, and the likelihood that governments will uphold contracts and not expropriate property, as well as the absence of corruption (see ibid).

20 For a detailed discussion of externalities and non-efficiency of unilateral rules, see Leebron (1996, note 4: 54, 55). For a summary of the arguments against harmonization of securities legislation, see below.

21 It is interesting to note that the European Union, after first having attempted to harmonize law in detail, has increasingly reverted to establishing minimum standards only and to support law-making and law enforcement at the lowest appropriate level (principle of subsidiarity).

22 Since, upon ratification of the Convention, it becomes part of the domestic law of a given country, an explicit statement of this sort is required to opt out of it. See Walt (1999, note 27).

23 Since a clarification of these terms and concepts requires that many parties look into the question and seek clarifi- cation of the terms, this practice might well render CISG ineffective, even though all parties may benefit in the long term from a uniform sales law for transnational transactions.

24 This term was coined by Means in his study of the underdeveloped law in Columbia (Means, 1980).

25 The extent of technical assistance required in this regard can range from introducing law reports that report new case law to computerized information systems.

26 For a more elaborate statement of this point see also Sunstein (1996b: 925). While his argument deals primarily with social norms, the point is also applicable to formal law.

27 For this approach see Hay et al. (1996), based on their experience with legal reforms in the Russian Federation.

28 See Black et al. (1996), and Black and Kraakman (1996) for a discussion of the educative function of law which they employed when drafting the model for the 1996 Russian corporate law.

29 Belcher (1995) quoting McBarnet and Whelan, who coined this term.

30 For a selection of cases that violate shareholder rights by using and misusing provisions of the corporate law, see Black et al. (1999).

31 See $\S 117$, section 7, of the German joint stock company law (AktG).

32 September 1998. The Securities Principles can be found on IOSCO's home page (www.iosco.org).

33 Zweigert and Kötz (1998) developed a functional approach to comparative law in general. For a critical assessment of this approach see Frankenberg (1985).

34 On this point see especially Coffee (1999a).

35 In chronological order these papers are: Pistor (1999 the paper was originally presented at the IRIS Conference on the Value of Law in Transition Economies, 5 March 1999); Coffee (1999b); and Johnson and Shleifer (1999). Johnson and Shleifer include more indicators than Pistor (1999), but come to very similar conclusions.

36 As will be further discussed below, CIS refer to mutual funds and other types of investment funds.

37 See p. 26 of the IOSCO Principles for these examples.

38 See section 10.5, p. 25, of the IOSCO Principles.

39 The IOSCO Principles mention that the said rules typically set the threshold well below a controlling interest. This is certainly of some help, but the contents of the final rule obviously depend on how a controlling interest is defined.

40 IOSCO Principles for the Regulation of Collective Investment Schemes, October 1994. Available on the IOSCO website (htp//:www. iosco.org/public_docs/).

41 The definition of CIS is "an open and collective investment scheme that issues redeemable units and invests primarily in transferable securities or money market instruments".

42 December 1999. The Insurance Principles can be found on the IAIS webpage (www.iaisweb.org).

43 Domestic law makers may officially support IAIS Principles, but define insurance business in such a way that only a few activities are actually governed by the Principles.

44 April 1999.

45 The approach is not consistently followed. In the Annotation to the "basic shareholder rights", the OECD CG Principles state: "This Section can be seen as a statement of the most basic rights of shareholders, which are recognised by law in virtually all OECD countries" (CG Principles: 12).

46 This literature was greatly influenced by Berle and Means (1932). For a critique of this paradigm and suggestions 
on how to expand the research on corporate governance, see Berglöf and von Thadden (1999).

47 On corporate governance problems in the Republic of Korea, see Kim (1996). A description of the pyramidal structure that can be found in the Republic of Korea's chaebols is included in La Porta et al. (1999).

48 The various legal indicators used in this study and the variance of these indicators across different transition economies is discussed in Pistor (2000).

49 In the aftermath of the Asian financial crisis, the restriction of portfolio capital inflows has been widely discussed as a possible policy option.

50 The authors focus on the introduction of formal legal systems in the nineteenth century and distinguish between countries of origin - i.e. countries that developed their formal legal systems internally - and transplant countries. The latter are further divided into transplants with (receptive) and without (unreceptive) a demand for the new law. Origins and receptive transplants today have more effective legal institutions than transplant countries.

51 For a historical analysis of the development of firms and legal responses between 1870 and 1933, see Spindler (1993).

52 The design of such rules or course does not guarantee that the law will be enforced, but is still an important prerequisite.

53 See Haley (1991: 67) for a discussion of Western legal transplants to Japan during the Meiji restoration.

\section{References}

BARFIELD CL (1996). International Financial Markets Harmonization versus Competition. Washington DC, American Economic Institute Press.

BEBCHUK L (1992). Federalism and the corporation: The desirable limits on State competition and the corporation. Harvard Law Review: 1437-1510

BELCHER A (1995). Regulation by the market: The case of the Cadbury Code and Compliance Statement. Journal of Business Law: 321-342.

BERGLÖF E and VON THADDEN EL (1999). The changing corporate governance paradigm: Implications for transition and developing countries. Proceedings of the Annual Bank Conference on Development Economics. Washington DC, World Bank.

BERKOWITZ D, PISTOR K and RICHARD JF (2000). Economic development, legality, and the transplant effect (mimeo). CID Working Papers, 39, Law and Development Paper No. 1. Cambridge MA, Center for International Development at Harvard University.

BERLE AA and MEANS G (1932). The Modern Corporation and Private Property. New York, Columbia University, Council for Research in the Social Sciences.

BLACK B AND KRAAKMAN R (1996). A self-enforcing model of corporate law. Harvard Law Review, 109: 1911-1982.

BLACK B, KRAAKMAN R and HAY JR (1996). Corporate law from scratch. In: Frydman R, Gray $\mathrm{CW}$ and Rapaczynski R, eds. Corporate Governance in Eastern Europe and Russia. Budapest, London and New York, Central European University Press: 245-302.

BLACK B, KRAAKMAN R and TARASSOVA A (1999). Russian Privatization and Corporate Governance: What Went
Wrong? Stanford, John M. Olin Program in Law and Economics.

BUXBAUM RM and HOPT KJ (1988). Legal Harmonization and the Business Enterprise. Berlin and New York, Walter de Gruyter.

BUXBAUM RM, HERTIG G, HIRSCH A and HOPT KJ , eds. (1991). European Business Law. Berlin and New York, Walter de Gruyter.

COFFEE JC Jr. (1999a). The future as history: The prospects for global convergence in corporate governance and its implications. Northwestern University Law Review 93(2): 631-707.

COFFEE JC (1999b). The lessons from securities market failure: Privatization, minority protection and investor confidence (draft). September.

CORNFORD A (1995). Risks and derivatives markets: Selected issues. UNCTAD Review, 1995. United Nations publication, sales no. E.95.II.D.23. New York and Geneva, UNCTAD: 189-212.

CORNFORD A (2000). The Basle Committee's proposals for revised capital standards: Rationale, design and possible incidence. G-24 Discussion Paper Series, 3. Geneva, UNCTAD, and Cambridge MA, Center for International Development, Harvard University.

FERRARINI G, ed. (1998). European Securities Markets - The Investment Services Directive and Beyond. London, The Hague and Boston, Kluwer Law International.

FRANKENBERG G (1985). Critical comparisons: Re-thinking comparative law. Harvard International Law Journal, 26(2): 411-455.

GILLETTE CP (1998). Lock-in effects in law and norms. Boston University Law Review, 78: 813-842.

GOLDSMITH RW (1969). Financial Structure and Development, Studies in Comparative Economics. New Haven, Yale University Press.

HALEY JO (1991). Authority Without Power. New York and Oxford, Oxford University Press.

HANSMANN H and MATTEI U (1995). Comparative Law and Economics of Trust. Berkeley CA, American Law and Economics Association.

HAY JR, SHLEIFER A and VISHNY RW (1996). Toward a theory of legal reform. European Economic Review 40(3-5): 559-567.

HUANG Haizhou and XU Chenggang (1999). Financial institutions, financial contagion and financial crises (draft). Washington DC, IMF.

IASC (1999). International Accounting Standards 1999. London: International Accounting Standards Committee.

JOHNSON S, BOONE P, BREACH A and FRIEDMAN E (1998). Corporate governance in the Asian financial crisis 1997-98. SITE Working Paper No. 137. Stockholm, Institute of Transtion Economies.

JOHNSON S and SHLEIFER A (1999). Coase vs. Coasians (draft). November.

KAMAR E (1998). A regulatory competition theory of indeterminacy in corporate law. Columbia Law Review, 98: 1908.

KAPLOW L (1992). Rules versus standards: An economic analysis. Duke Law Journal, 42: 557-629.

KIM, KS (1996). Chaebol and corporate governance in Korea. In: Song, ed. Korean Law in the Global Economy. Seoul, Bak Young Sa Publishing Co.: 598-677.

LA PORTA R, LOPEZ-DE-SILANES F, SHLEIFER A and VISHNY RW (1998). Law and finance. Journal of Political Economy, 106(6): 1113-1155.

LA PORTA R, LOPEZ-DE-SILANES F and SHLEIFER A (1999). Corporate ownership around the world. Journal of Finance, LIV(2): 471-517. 
LEEBRON DW (1996). Lying down with procrustes: An analysis of harmonization claims. In: Bhagwati $\mathbf{J}$ and Hudec RE, eds. Fair Trade and Harmonization (two volumes). Cambridge MA, MIT Press, 1: 41-118.

LEVINE R (1998). The legal environment, banks, and long-run economic growth. Journal of Money, Credit, and Banking, 30(3): 596-613.

LEVINE R and ZERVOS S (1996). Stock Markets, Banks, and Economic Growth. Washington DC, World Bank

MEANS RC (1980). Underdevelopment and the Development of Law. Chapel Hill: The University of North Carolina Press.

PISTOR K (1999). Law as a determinant for stockmarket development in Eastern Europe. In: Murrell P, ed. The Value of Law in Transition Economies. Baltimore MD, IRIS Center, University of Maryland.

PISTOR K (2000). Patterns of legal change: Shareholder and creditor rights in transition economies. European Business Organization Law Review, 1(1): 59-110.

PISTOR K, RAISER M and GELFER S (1999). Law and finance in transition economies (mimeo). London, Euroean Bank for Reconstruction and Development.

ROMANO R (1993). The Genius of American Corporate Law. Washington DC, American Economic Institute.

ROMANO R (1998). Empowering investors: A market approach to securities regulation. The Yale Law Journal, 107: 2359-2430.

SCHWARTZ A and SCOTT RE (1995). The political economy of private legislatures. University of Pennsylvania Law Review, 143(3): 595-654.
SPINDLER G (1993). Recht und Konzern - Interdependenzen der Rechts- und Unternehmensentwicklung in Deutschland und den USA zwischen 1870 und 1933 [Law and Concern: Interdependencies between legal and company development in Germany and the United States between 1870 and 1933]. Tübingen, JCB Mohr (Paul Siebeck).

SUNSTEIN CR (1996a). On the expressive function of law. University of Pennsylvania Law Review, 144: 2021-2053.

SUNSTEIN CR (1996b). Social norms and social roles. Columbia Law Review, 96: 903-968.

WALT W (1999). Novelty and the risks of uniform sales law. Virginia Journal of International Law, 39(3): 671-706.

WARREN MG.III(1990). Global harmonization of securities laws - The achievements of the European Communities. Harvard International Law Journal, 185.

WEF (2000). Competitiveness Report (2000). Geneva, World Economic Forum, and Cambridge MA, Center for International Development.

WHITE LJ (1996). Competition versus harmonization - An overview of international regulation of financial services. In: Barfield CE (1996). International Financial Markets - Harmonization versus Competition. Washington DC, American Economic Institute Press: 5-48.

WOODRUFF DM (1999). Rules for Followers: Institutional Theory, Russia, and the New Politics of Economic Backwardness. Cambridge MA, Davis Center for Russian Studies.

ZWEIGERT K and KÖTZ H (1998). Introduction to Comparative Law (third edition). Oxford, Clarendon Press. 


\section{G-24 Discussion Paper Series*}

Research papers for the Intergovernmental Group of Twenty-Four on International Monetary Affairs

No. 1 March 2000 Arvind PANAGARIYA $\begin{aligned} & \text { The Millennium Round and Developing Countries: Nego- } \\ & \text { tiating Strategies and Areas of Benefits }\end{aligned}$

No. 2 May $2000 \quad$ T. Ademola OYEJIDE Interests and Options of Developing and Least-developed Countries in a New Round of Multilateral Trade Negotiations

No. 3 May 2000 Andrew CORNFORD The Basle Committee's Proposals for Revised Capital Standards: Rationale, Design and Possible Incidence

* G-24 Discussion Paper Series are available on the website at: http://www.unctad.org/en/pub/pubframe.htm. Copies of G-24 Discussion Paper Series may be obtained from c/o Editorial Assistant, Macroeconomic and Development Policies Branch, Division on Globalization and Development Strategies, United Nations Conference on Trade and Development (UNCTAD), Palais des Nations, CH-1211 Geneva 10, Switzerland; Tel. (+41-22) 907.5733; Fax (+41-22) 907.0274; E-mail: nicole.winch@unctad.org 